\title{
Peningkatan Phycocyanin pada Spirulina Platensis dengan Media Limbah Virgin Coconut Oil pada Photobioreactor Tertutup
}

\author{
Sri Sukadarti*, Sri Wahyu Murni dan M. Maulana Azimatun Nur \\ Program Studi Teknik Kimia UPN “Veteran” Yogyakarta, \\ Jl SWK 104 Condongcatur, Yogyakarta, 55283Indonesia
}

\section{Artikel histori : \\ Diterima September 2016 Diterima dalam revisi Oktober 2016 Diterima November 2016 Online Juni 2017}

\begin{abstract}
ABSTRAK: Limbah industri Virgin Coconut Oil mempunyai nilai Chemical Oxygen Demand (COD) yang cukup tinggi sehingga menimbulkan masalah bagi lingkungan. Limbah ini memiliki kandungan bahan organik seperti minyak, protei, karbohidrat dan beberapa mineral, sehingga berpotensi untuk dimanfaatkan sebagai media tumbuh alga hijau biru Spirulina plantesis. Spirulina plantesis mengandung phycocyanin yang bersifat anti penuaan, anti oksidan dan anti inflammatory, oleh karenanya Spirulina platensis berharga tinggi. Penelitian ini bertujuan untuk mempelajari pengaruh penambahan urea dan intensitas cahaya terhadap pertumbuhan spirulina, kadar phycocyanin dan penurunan COD limbah. Spirulina platensis dikultivasi pada photobioreactor tertutup dengan pengaliran udara selama 7 hari. Intensitas cahaya divariasi 5000 lux, 6000 lux, 7000 lux dan 8000 lux, sedangka penambahan urea sebagai nutrisi divariasi $40 \mathrm{ppm}, 50 \mathrm{ppm}, 60 \mathrm{ppm}$ dan $70 \mathrm{ppm}$. Pada penelitian ini didapat kondisi terbaik pada penambahan urea $70 \mathrm{ppm}$ dan intensitas cahaya 6000 lux dengan hasil $\mu_{\max } 1,1375$ hari $^{-1}$, produktivitas $0,0423 \mathrm{~g} / \mathrm{l} / \mathrm{hari}$, konsentrasi biomassa $0,1734 \mathrm{~g} / \mathrm{l}$ dan kadar phycocyanin 5,047 \%. Penurunan kadar COD limbah VCO terbesar 98,06\% dan didapat nilai COD $280 \mathrm{mg} / \mathrm{l}$.
\end{abstract}

Kata Kunci: phycocyani; Spirulina platensis; VCO; photobioreactor

\begin{abstract}
Waste of Virgin Coconut Oil (VCO) industries has a high value of Chemical Oxygen Demand (COD), it is therefore a problem for the environment. This waste contains organic materials such as oil, proteins, carbohydrates and some minerals, that potentially to be used for the cultivation of blue-green algae Spirulina plantesis. Spirulina plantesis is an excellent source of phycocyanin. The Phycocyanin has anti-aging, anti-oxidant and antiinflammatory properties, so high value. This research is aimed to study the effects of the addition of urea and light intensity on the growth of Spirulina, the concentration of phycocyanin and decreasing of COD value. Spirulina platensis was cultivated in a closed photobioreactor with an air flow for 7 days continuosly. The light intensity was varied as follows 5000 lux, 6000 lux, 7000 lux and 8000 lux, and the addition of urea as nutrients was also varied as follows $40 \mathrm{ppm}, 50 \mathrm{ppm}, 60 \mathrm{ppm}$ and $70 \mathrm{ppm}$. This research indicated that the optimum condition was obtained at the addition of urea of $70 \mathrm{ppm}$, light intensity of 6000 lux. This research resulted $\mu_{\max }$ of 1,1375 day $^{-1}$, the biomass productivity of $0,0423 \mathrm{~g} / \mathrm{l} / \mathrm{day}$, biomass concentration of $0,1734 \mathrm{~g} / \mathrm{l}$ and phycocyanin concentration of 5,047\%. The largest of COD removal was $98,06 \%$ and the COD value of $280 \mathrm{mg} / \mathrm{l}$ was finally achieved.
\end{abstract}

Keywords: phycocyanin; Spirulina plantesis; VCO; photobioreactor

\section{Pendahuluan}

Indonesia merupakan negara penghasil kelapa yang cukup besar, dari Renstra Kementerian Pertanian Republik Indonesia 2015-2019 estimasi produksi kelapa tahun 2014 mencapai 3.262.721 ton. Salah satu produk olahan kelapa yang cukup berkembang adalah Virgin Coconut Oil (VCO) .VCO adalah hasil olahan santan yang bermanfaat untuk kesehatan dan kosmetik. Hampir di semua daerah penghasil kelapa, ada banyak usaha kecil dan menengah yang memproduksi VCO. Santan yang digunakan untuk pembuatan VCO adalah bagian krim santan (bagian yang kaya minyak) sedang skim santan/ santan encer umumnya tidak dimanfaatkan dan dibuang ke lingkungan. Skim santan masih mengandung sedikit minyak, protein, karbohidrat dan beberapa mineral sehingga kalau dibuang ke lingkungan akan mencemari lingkungan.

*Corresponding Author:

Email: sukadartisri@yahoo.com 
Menurut penelitian Azimatun Nur dkk (2015) skim santan limbah produksi VCO mengandung COD 4916,67 ppm, BOD5 983,33 ppm, phospat 0,70 ppm, N total 104,16 ppm dan minyak 0,5 ppm dapat dimanfaatkan untuk membudidayakan Spirulina platensis sehingga dapat menurunkan kadar pencemar sekaligus dapat menaikkan nilai tambah pengolahan kelapa karena harga Spirulina platensis yang tinggi.

Spirulina platensis adalah alga hijau biru yang mengandung sedikit asam nukleat, protein 55\%-70\%, lemak 6\%-9\%, karbohidrat $15 \%-20 \%$ dan diperkaya mineral, vitamin, serat dan pigmen ( Yong Chang Seo et.al, 2013). Protein dalam Spirulina platensis adalah protein yang unik dikenal sebagai chromoprotein/ phycobiliprotein. Berdasarkan strukturnya phycobiliprotein diklasifikasikan menjadi tiga golongan yaitu : phycoerythrins, phycocyanin (pigmen biru) dan allophycocyanin. Phycocyanin adalah pigmen biru yang berfungsi sebagai penyimpan cadangan nitrogen pada Cyanobacteria. Phycobiliprotein merupakan tetrapyrrol yang berikatan kovalen dalam berbagai kombinasi dengan komplek protein. Biliprotein terbentuk dari protoporphyrin yang pada tahap akhir mekanisme reaksinya adalah terbukanya cincin porphyrin secara oksidasi sehingga dihasilkan biliprotein dan gas karbon monoksida ( Cheung,S.2000). Phycocyanin inilah zat aktif yang membuat Spirulina platensis berharga tinggi. Hasil penelitian menunjukkan bahwa phycocyanin bersifat anti penuaan, anti oksidan dan anti inflammatory sehingga dapat menekan pertumbuhan sel kanker (Yong Chang Seo et.al, 2013). Selama ini phycocyanin digunakan sebagai pewarna dalam makanan, kosmetik dan produk farmasi. Untuk meningkatkan kadar phycocyanin perlu dipelajari faktor-faktor yang berpengaruh terhadap pertumbuhan Spirulina platensis .

Faktor-faktor yang berpengaruh dalam pertumbuhan Spirulina platensis adalah :

1. Intensitas cahaya.

Intensitas cahaya sangat diperlukan dalam proses fotosintesis sebagai sumber energi. Kekurangan intensitas cahaya akan berakibat lambatnya laju fotosintesis sehingga pertumbuhan sel akan lambat. Tetapi jika intensitas cahaya berlebihan, dapat terjadi dua hal yaitu photoinhibisi yang berakibat melambatnya laju pertumbuhan sel karena jenuh dan photooksidasi yang menyebabkan kerusakan sel (Rangel-Yagui.et.al, 2004)

2. Temperatur.

Spirulina platensis mempunyai temperatur pertumbuhan optimum $35^{\circ} \mathrm{C}$ dan diatas $38^{\circ} \mathrm{C} S$. platensis akan mati ( Jourdan, 2001)

3. Nutrien.

Spirulina plantesis membutuhkan nutrisi makro adalah karbon, nitrogen, pospor, garam klorida, kalium serta nutrisi mikro berupa ion besi dan vitamin. Penambahan sodium bikarbonat dapat sebagai sumber karbon dan jika Spirulina platensis ditumbuhkan dalam air tawar perlu ditambah $\mathrm{NaCl}$ untuk salinitas.
Nitrogen berpengaruh terhadap pembentukan khlorofil, urea merupakan sumber nitrogen yang lebih baik di banding senyawa nitrat karena urea lebih mudah terhidrolisis menjadi ammonia pada suasana alkali dan ammonia lebih mudah diasimilasi oleh $S$. platensis, tetapi jika konsentrasinya tinggi ammonia bisa menjadi racun ( Rangel-Yagui,et.al, 2004)

4. Oksigen .

Oksigen menjadi faktor pengganggu dalam pertumbuhan alga, sehingga pengaliran udara sebagai sumber $\mathrm{CO}_{2}$ yang berlebihan tidak menguntungkan (Hadiyanto dan Maulana Azim, 2012).

5. $\mathrm{pH}$

Spirulina platensis tumbuh baik pada suasana basa, pH optimum pada kisaran $\mathrm{pH}$ 9-10 .

6. Karbon Dioksida

Karbon dioskida digunakan mikroalga untuk proses fotosintetis layaknya tumbuhan berklorofil lainnya, tetapi penambahan $\mathrm{CO}_{2}$ yang berlebihan menyebabkan penurunan $\mathrm{pH}$ larutan karena terbentuknya asam karbonat .

Pertumbuhan Spirulina.platensis juga dipengaruhi oleh jenis reaktor, reaktor sistem tertutup lebih menguntungkan dibanding reaktor sstem terbuka. Keuntungannya adalah tidak mudah terkontaminasi, efisien dan efektif dalam pencahayaan, tidak banyak $\mathrm{CO}_{2}$ yang hilang, tidak membutuhkan area yang luas. Penelitian ini bertujuan untuk mempelajari pengaruh penambahan urea dan intensitas cahaya terhadap pertumbuhan spirulina, kadar phycocyanin dan penurunan COD limbah VCO.

\section{Metode Penelitian}

\subsection{Bahan dan alat}

Bahan baku yang digunakan pada penelitian ini adalah limbah cair produksi VCO diperoleh dari CV Masyana Barokah Mulya, Bambanglipuro, Bantul, Yogyakarta. Limbah disaring kemudian dipanaskan pada $70^{\circ} \mathrm{C}$ selama 30 menit untuk mencegah kontaminasi dan kemudian didinginkan sampai suhu kamar dan dilakukan analisis COD. Kultur Spirulina platensis didapat dari CV Neoalgae Rejosari, Tawangsari, Sukoharjo, Jawa Tengah. Bahan untuk nutrisi : $\mathrm{NaHCO}_{3}$, Urea,TSP, $\mathrm{NaCl}$, Vitamin B12 serta bahan untuk analisis COD dan Phycocyanin. Rangkaian alat kultivasi Spirulina platensis disajikan pada Gambar 1.

\subsection{Cara kerja}

\section{Aklimatisasi Spirulina platensis}

Spirulina platensis sebanyak $2000 \mathrm{ml}$ ditambah 12 gram/liter natrium bikarbonat $\left(\mathrm{NaHCO}_{3}\right), 240$ ppm pupuk urea, 120 ppm pupuk TSP, 12000 ppm NaCl, $1200 \mathrm{ml}$ vitamin B12, $1200 \mathrm{ml}$ skim VCO dan air $6000 \mathrm{ml}$ dengan pH 9,5 dan dialiri udara . 


\section{Pembuatan Kurva standar konsentrasi biomassa.}

Kurva standar dibuat dengan cara mencampur biomassa Spirulina platensis kering berat tertentu dengan media tumbuh yang sudah ditambah nutrisi dengan volume tertentu sehingga didapat konsentrasi biomassa (g/l) tertentu. Optical density (OD) larutan diukur dengan spektrofotometer pada panjang gelombang $680 \mathrm{~nm}$ (Borowitzka dan Lesley, 1988), sehingga dapat dibuat kurva hubungan optical density dengan konsentrasi biomassa.

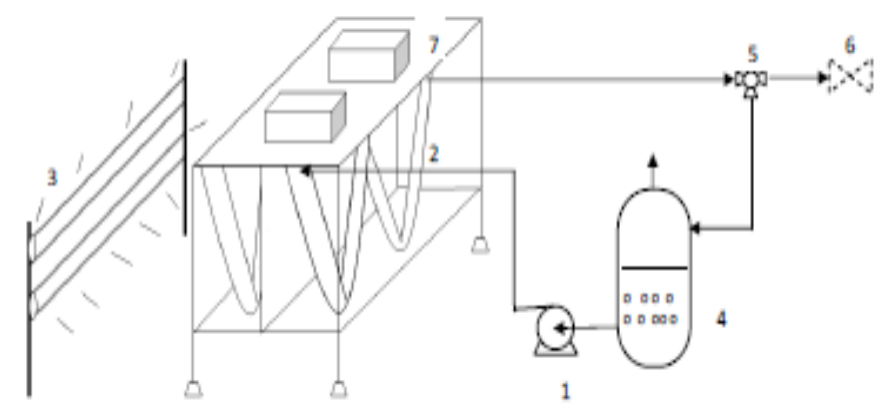

Keterangan:
1. pompa
2. tabung kultivasi
3. lampu neon
4. tanki induk
5. valve
6. kran panen
7. aerator

Gambar 1. Rangkaian alat penelitian

\section{Pertumbuhan Spirulina platensis}

Kultur Spirulina platensis yang telah di aklimatisasi ditambah limbah cair VCO steril dengan nutrisi $\mathrm{NaHCO}_{3}$, TSP, vitamin B12 dan Urea yang di variasi 40, 50,60 dan 70 (ppm), diatur $\mathrm{pH}$ nya $\pm 9,5$ kemudian ditumbuhkan pada photobioreactor tertutup dengan mengalirkan udara melalui aerator. Cahaya diperoleh dari lampu neon 25 watt dengan intensitas cahaya divariasi 5000, 6000, 7000 dan 8000 ( lux). Pertumbuhan dilakukan selama 7 hari dan pada akhir pertumbuhan dilakukan analisa phycocyanin menggunakan metode Boussiba S. and A. Richmond.( 1979), dan analisa kadar COD mengikuti Standard Methods for the Examination of Water and Wastewater (APHA, AWWA, WCF, 1992)

\section{Pengukuran Hasil Percobaan}

Pengukuran pertumbuhan biomassa dilakukan dengan mengukur optical density larutan menggunakan spektrofotometer dengan panjang gelombang $680 \mathrm{~nm}$. Pengukuran dilakukan setiap hari dari awal inokulasi sampai hari ke 7. Dengan bantuan kurva standar maka konsentrasi biomassa dapat diketahui. Laju pertumbuhan spesifik maksimum $(\mu \quad \max )$ diukur pada phase pertumbuhan eksponensial dengan persamaan 1 .

$$
\mu_{m=\frac{\ln x_{2}-\ln x_{1}}{t_{2}-t_{1}}} \operatorname{hari~}^{-1}
$$

dengan

$\mathrm{X}_{1}=$ konsentrasi biomassa pada awal fase eksponensial $\left(\mathrm{t}_{1}\right)$

$\mathrm{X}_{2}=$ konsentrasi biomassa pada akhir fase eksponensial

$\left(\mathrm{t}_{2}\right)$

Sedang produktivitas rata-rata dihitung dengan persamaan 2.

$$
\mathrm{P}=\frac{\mathrm{X}_{\mathrm{t}}-\mathrm{X}_{0}}{\mathrm{t}_{\mathrm{t}}}, \mathrm{mg} / \mathrm{l} / \mathrm{hari}
$$

dengan

$\mathrm{X}_{\mathrm{t}}=$ konsentrasi biomassa maksimum

$\mathrm{X}_{0}=$ Konsentrasi biomassa pada awal kultivasi

$\mathrm{t}_{\mathrm{t}}=$ waktu kultivasi untuk mencapai konsentrasi

maksimum

\section{Perhitungan Kandungan Phycosianin dan \% Penurunan COD}

Kadar phycocyanin dihitung dengan persamaan 3 .

$$
\% \text { pure } \mathrm{CPC}=\frac{\mathrm{A}_{620} \times(10) \times 100}{7,3 \times(\mathrm{mg} \text { sampel })}
$$

dengan: $\mathrm{A}_{620}$ : Optical density pada $620 \mathrm{~nm}$

7,3 : koefisien CPC pada $620 \mathrm{~nm}$

10 : volume total

Penurunan kadar COD pada limbah dihitung dengan persamaan 4 .

$$
\frac{\mathrm{COD}_{0}-\mathrm{COD}_{\mathrm{t}}}{\mathrm{COD}_{0}} \times 100 \%
$$

\section{Hasil dan Pembahasan}

\section{Pengukuran COD limbah VCO}

Hasil analisis kadar COD dalam limbah VCO sebelum digunakan sebagai media pertumbuhan spirulina adalah 15.022 ppm, sedangkan menurut Peraturan Menteri Lingkungan Hidup RI no 5 tahun 2014 kadar COD dalam limbah pengolahan kelapa yang diijinkan untuk dibuang ke lingkungan adalah $150 \mathrm{ppm}$.

Pengaruh penambahan Urea dan Intensitas cahaya terhadap laju pertumbuhan Spirulina platensis, kadar phycocianin dan penurunan COD limbah VCO.

Urea merupakan sumber Nitrogen yang merupakan salah satu nutrisi penting yang berpengaruh terhadap metabolisme dan pertumbuhan mikroalga pada umumnya, sedangkan intensitas cahaya yang diadsorpsi oleh sel mikroalga dipengaruhi oleh kandungan pigmen dalam mikroalga dan akan berpengaruh terhadap densitas sel. Hasil percobaan untuk mempelajari pengaruh penambahan urea dan intensitas cahaya terhadap pertumbuhan spirulina platensis dapat dilihat pada Tabel 1 . 
Tabel.1 Laju pertumbuhan spesifik, produktivitas biomassa, kadar phicocyanin dan $\%$ penurunan COD pada berbagai penambahan urea dan intensitas cahaya pada $\mathrm{pH}$ awal 9,5 dan temperatur $28-30^{\circ} \mathrm{C}$

\begin{tabular}{|c|c|c|c|c|c|c|}
\hline \multirow{2}{*}{$\begin{array}{l}\text { Urea } \\
\text { (ppm }\end{array}$} & \multirow{2}{*}{$\begin{array}{l}\text { Intensitas } \\
\text { cahaya } \\
\text { (lux) }\end{array}$} & \multirow{2}{*}{$\underset{\left(\text { hari }^{-1}\right)}{\mu_{\max }}$} & $\mathbf{P}$ & СРC & \multirow{2}{*}{$\begin{array}{c}\text { Penurunan } \\
\text { COD }(\%)\end{array}$} & \multirow{2}{*}{$\begin{array}{c}\text { Kadar COD } \\
\text { akhir } \\
(\mathrm{mg} / \mathrm{l})\end{array}$} \\
\hline & & & (mg/L/hari) & $(\%)$ & & \\
\hline 40 & 5000 & 0.7691 & 0.0078 & 0,616 & 82,30 & 2760 \\
\hline 40 & 6000 & 0.7613 & 0.0133 & 0,862 & 83,20 & 2620 \\
\hline 40 & 7000 & 0.7816 & 0.016 & 1,188 & 85,38 & 2280 \\
\hline 40 & 8000 & 0.8606 & 0.0187 & 1,123 & 85,17 & 2312 \\
\hline 50 & 5000 & 0.851 & 0.0196 & 1,297 & 85,83 & 2210 \\
\hline 50 & 6000 & 0.8577 & 0.0237 & 1,424 & 86,40 & 2120 \\
\hline 50 & 7000 & 0.8841 & 0.0264 & 2,030 & 86,92 & 2040 \\
\hline 50 & 8000 & 0.9394 & 0.0321 & 1,904 & 85,57 & 2085 \\
\hline 60 & 5000 & 0.9299 & 0.0301 & 2,253 & 86,44 & 1960 \\
\hline 60 & 6000 & 0.9804 & 0.0368 & 2,613 & 87,82 & 1760 \\
\hline 60 & 7000 & 0.9356 & 0.0368 & 2,811 & 89,21 & 1560 \\
\hline 60 & 8000 & 0.997 & 0.0377 & 2,664 & 88,40 & 1677 \\
\hline 70 & 5000 & 0.9338 & 0.0382 & 3,164 & 92,53 & 1080 \\
\hline 70 & 6000 & 1.1375 & 0.0423 & 5,047 & 97,20 & 405 \\
\hline 70 & 7000 & 1.1228 & 0.0424 & 5,232 & 98,06 & 280 \\
\hline 70 & 8000 & 1.1218 & 0.0421 & 5,106 & 97,59 & 349 \\
\hline
\end{tabular}

Hasil percobaan menunjukkan bahwa penambahan urea yang semakin besar akan meningkatkan laju pertumbuhan spesifik maksimum maupun produktivitas biomassa Spirulina platensis, hal ini disebabkan karena penambahan urea berpengaruh terhadap jumlah khlorofil yang terbentuk. Khlorofil mengandung chloroplast yang mengkatalisis perubahan $\mathrm{CO}_{2}$ menjadi karbohidrat (biomassa) dalam reaksi fotosintesis .Laju reaksi fotosintesis juga dipengaruhi oleh jumlah energi yang diserap.

Pengaruh intensitas cahaya terhadap kenaikan konsentrasi biomassa terlihat jelas pada penambahan urea 40ppm dan $50 \mathrm{ppm}$, karena pada kondisi ini khlorofil yang terbentuk masih sedikit maka laju pembentukan biomassa juga lambat, kenaikan energi yang diserap akan meningkatkan biomassa yang terbentuk karena nutrisi dalam media masih cukup. Sedangkan pada penambahan urea yang lebih banyak yaitu $60 \mathrm{ppm}$ dan $70 \mathrm{ppm}$ pengaruh kenaikan intensitas cahaya dari 6000 lux, 7000 lux dan 8000 lux hampir tidak memberikan pengaruh terhadap laju pertumbuhan spesifik maksimum dan produktivitas. Hal ini karena pada intensitas cahaya 6000 lux penyerapan energi sudah mengalami kejenuhan sehingga penambahan intensitas cahaya sudah tidak mampu lagi diserap oleh Spirulina platensis dan terjadi photoinhibisi.

Kondisi optimum untuk pertumbuhan diperoleh pada penambahan urea $70 \mathrm{ppm}$ dengan intensitas cahaya 6000 lux dengan harga $\mu_{\max }$ sebesar 1,1375 hari $^{-1}$, produktivitas $0,0423 \mathrm{~g} / \mathrm{L} / \mathrm{hari}$ dan konsentrasi biomassa $0,1744 \mathrm{~g} / \mathrm{l}$.

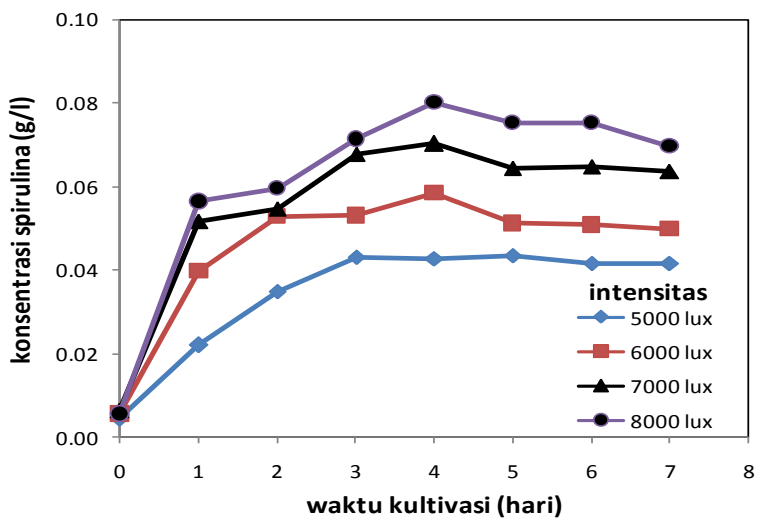

Gambar 2. Pertumbuhan Spirulina platensis pada penambahan Urea 40 ppm

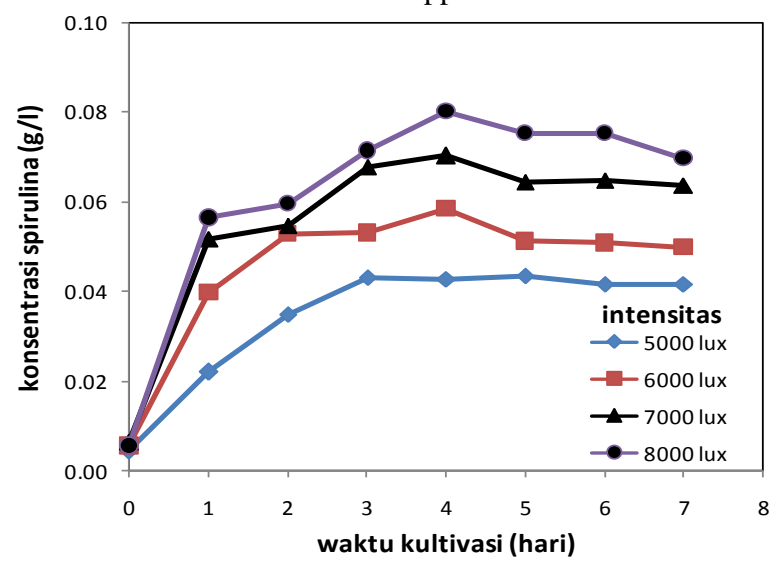

Gambar 3. Pertumbuhan Spirulina platensis pada penambahan Urea 50 ppm 


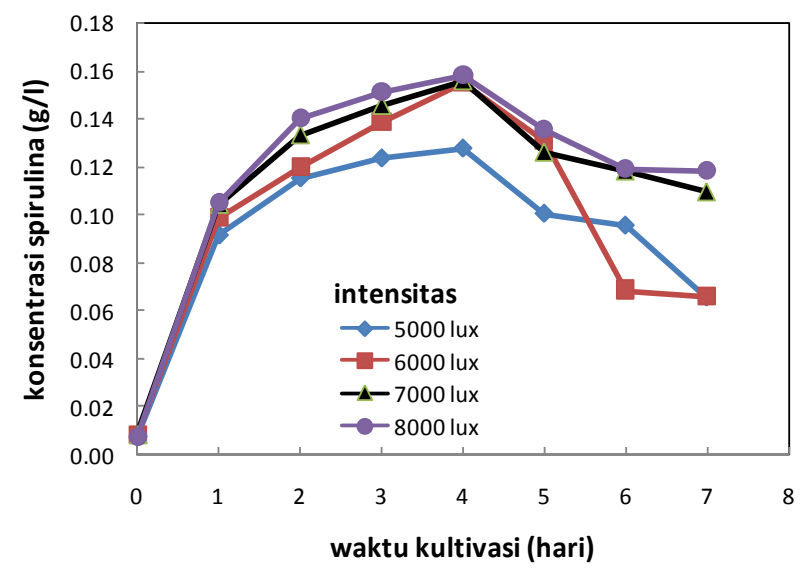

Gambar 4. Pertumbuhan Spirulina platensis pada penambahan Urea $60 \mathrm{ppm}$

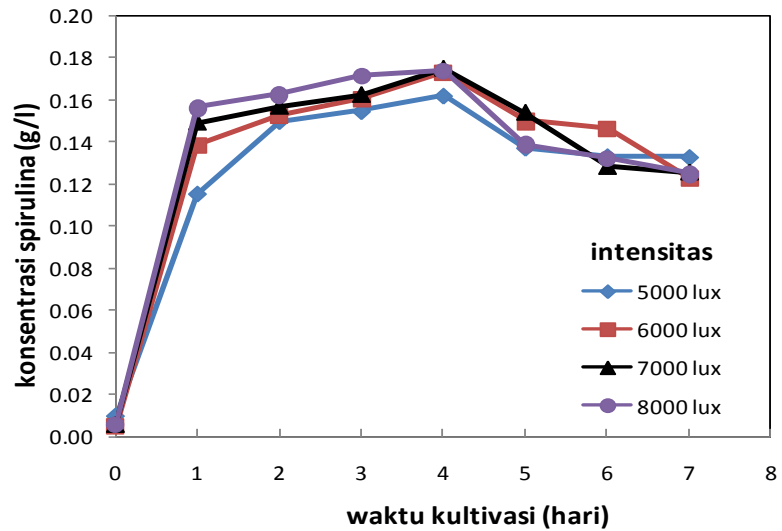

Gambar 5. Pertumbuhan Spirulina platensis pada penambahan Urea $70 \mathrm{ppm}$

Phycocyanin adalah protein yang ada pada biomassa yang dihasilkan oleh reaksi fotosintesis. Pengaruh penambahan urea dalam medium pertumbuhan terhadap kadar phycocyanin terlihat pada gambar 6. Penambahan jumlah urea akan menambah jumlah nitrogen dalam media, sehingga protein yang dihasilkan juga semakin besar. Pada penambahan urea $40 \mathrm{ppm}, 50 \mathrm{ppm}$ dan $60 \mathrm{ppm}$, peningkatan intensitas cahaya kurang berpengaruh terhadap kadar phycocyanin hasil, hal ini dikarenakan jumlah nitrogen dalam media kurang sehingga phycocyanin yang dihasilkan juga hanya sedikit naik meskipun intensitas cahayanya dinaikkan. Hal ini berbeda pada penambahan urea 70 ppm dengan intensitas cahaya yang dinaikkan dari 5000 lux ke 6000 lux terlihat kadar phycocyanin naik dengan tajam tetapi setelah itu penambahan intensitas cahaya tidak banyak berpengaruh. Phenomena ini terjadi karena pada penambahan urea 70 ppm kadar nitrogen dalam media cukup sehingga dengan penambahan energi laju pembentukan protein juga bertambah. Tetapi ketika intensitas cahaya ditambah menjadi 7000 lux kadar phycocyanin hanya bertambah sedikit cenderung konstan , hal ini karena penyerapan energi sudah mendekati jenuh . Pada penambahan intensitas cahaya 8000 lux, kadar phycocyanin mengalami sedikit penurunan, kemungkinan penambahan intensitas cahaya menyebabkan photoinhibisi dan photooksidasi sehingga merusak pigmen. Kondisi yang terbaik didapat pada penambahan urea $70 \mathrm{ppm}$, intensitas cahaya 6000 lux dengan hasil phycocyanin 5,047\%.

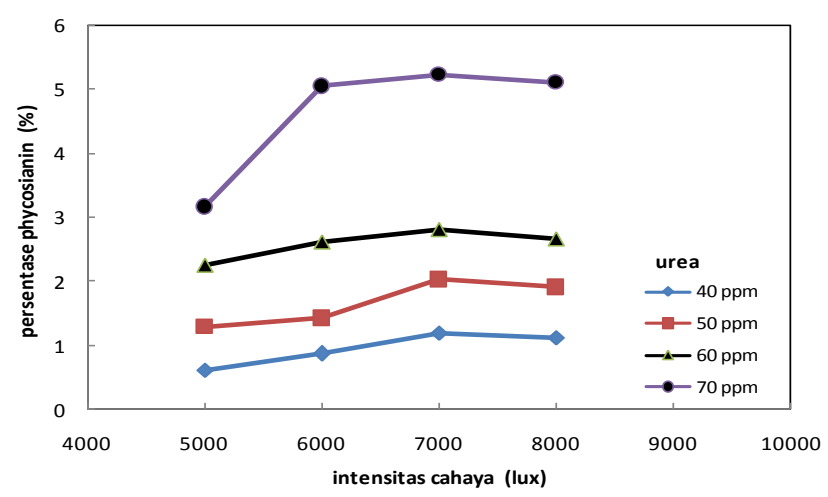

Gambar 6. Kadar phycocyanin pada berbagai penambahan urea

Pengaruh penambahan urea dan intensitas cahaya terhadap penurunan kadar COD dalam limbah VCO digambarkan pada gambar 7. Penurunan nilai COD pada media disebabkan oleh konsumsi minyak, karbohidrat dan protein yang ada pada limbah oleh mikroalga. Semakin besar laju pertumbuhan Spirulina.platensis maka semakin besar penurunan COD. Hal ini terlihat dari kesesuaian laju produksi biomassa dengan laju penurunan kadar COD limbah VCO. Penurunan COD terbaik didapat pada penambahan urea 70 ppm dengan intensitas cahaya 7000 lux dengan kadar $280 \mathrm{mg} / \mathrm{l}$. Tetapi penurunan kadar COD limbah VCO ini belum dapat mencapai kadar COD yang diijinkan untuk industri pengolahan kelapa yaitu $150 \mathrm{mg} / \mathrm{l}$.

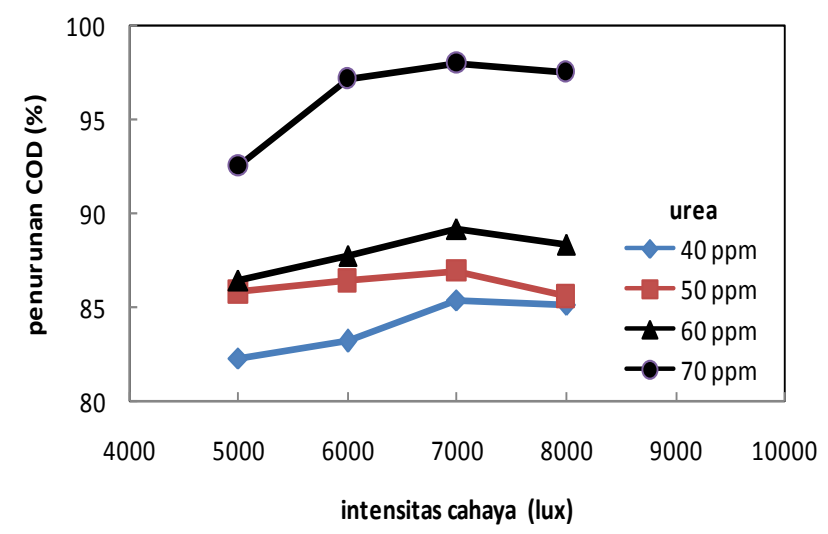

Gambar 7. Penurunan kadar COD pada limbah VCO pada berbagai penambahan urea dan intensitas cahaya

\section{Kesimpulan}

Kondisi optimum pertumbuhan Spirulina platensis pada limbah VCO didapat pada penambahan urea 70 ppm, intensitas cahaya 6000 lux , pH awal 9,5 , temperatur 28$30^{\circ} \mathrm{C}$ dengan hasil $\mu_{\max } 1,1375$ hari $^{-1}$, produktivitas $0,0423 \mathrm{~g} / \mathrm{l} / \mathrm{hari}$, konsentrasi biomassa $0,1734 \mathrm{~g} / \mathrm{l}$ dan kadar phycocyanin $5,047 \%$. 
Penurunan COD pada limbah VCO terbanyak adalah $98,06 \%$ didapat pada kondisi penambahan urea $70 \mathrm{ppm}$, intensitas cahaya 7000 lux, pH awal 9,5 , temperatur 28$30^{\circ} \mathrm{C}$, dengan nilai COD akhir $280 \mathrm{mg} / \mathrm{l}$ belum memenuhi standar nilai COD limbah industri pengolahan kelapa yaitu $150 \mathrm{mg} / \mathrm{l}$.

\section{Ucapan Terima kasih}

Penulis mengucapkan terimakasih kepada Lembaga Penelitian dan Pengabdian kepada Masyarakat UPN "Veteran" Yogyakarta, atas pemberian bantuan dana untuk penelitian ini. Juga kepada saudara Siti Nurjanah dan Nurul Islamy Putra yang telah membantu dalam pengambilan data.

\section{Daftar Pustaka}

APHA, AWWA, and WPCF, 1992, Standard Methods for The Examination of Water and Wastewater, American Public Health Association, Washington DC.

Azimatun Nur,M.M; Irawan,M.A; Hadiyanto, 2015. Utilization of Coconut Milk Skim Effluent (CMSE) as Medium Growth for Spirulina plantesis. Procedia Enviromental Sciences 23(2015)72-77, Elsevier

Boussiba S. and A. Richmond. 1979. Isolation and purification of phycocyanins from the blue-green alga Spirulina platensis. Arch. Microbiol. 120:155159.

Chung,S,2000. The Growth Characteristics of Spirulina platensis under Photoautotrophic and Mixotrophic Conditions. (Thesis). University of Hong Kong, Pokfulam,Hong Kong SAR.Retrieved from http://dx.doi.org/10.5353/th_b3122236

Hadiyanto dan Maulana Azim, 2012, Mikroalga Sebagai Sumber Pangan dan Sumber Energi Masa Depan, Cetakan pertama ,UPT UNDIP Pres, Semarang

Yong Chang Seo, Woo Seok Choi, Jong Ho Park, Jin Oh Park, Kyung-Hwang Jun and Hyeon Yong Lee, 2013, "Stable Isolation of Phycocyanin from Spirulina platensis Associated with High- Pressure Extraction Process", International Journal of Moleculer Sciences $14,1778-1787$

Rangel-Yagui, C.O; Danesi,E.D.G; Carvalho,J.C.M; Sato, Sunao; 2004, Chlorophill Production from Spirulina 